\title{
PROCEDIMENTO DO EFEITO INCONSCIENTE DO FANTÁSTICO EM HAMLET
}

\section{Silvia Beatriz Bolotin}

\author{
"O fantástico \\ sobrenatural ou insólito, \\ anormal ou monstruoso, \\ faz suspeitar \\ a existência de \\ uma ordem oculta".
}

Bella Jozef. $^{1}$

Com Hamlet, e com Júlio Cesar (1599-60), que o anuncia, estamos no ciclo chamado negro das grandes tragédias, em que não se trata de um retorno às impudicas e atrozes verdades, mas em que os personagens parecem adaptar-se a uma negação sem recursos diante do espanto de uma intolerável visão.

Hamlet foi escrita em 1601, ou 1602, por William Shakespeare, depois da morte de seu pai, e Romeu e Julieta (1595-96) nos chega como uma sinfonia de dor perene sobre amores apaixonados a seu filho Hamnet, que morreu em 1596, aos onze anos de idade. Fazendo conjeturas a partir do meu inconsciente de leitora, percebo um Hamlet em ressonância com o desaparecimento do filho e do pai, mas como antítese em relação a Romeu e Julieta, em que Hamnet recebe uma homenagem imortal com um aroma nostálgico pela separação de William e Anne Hathaway. Constata-se que, na estrutura da linguagem em Hamlet, aparecem representações de paixões criminosas, em que faz falta saber a origem da sepultura do símbolo em relação ao conceito de iluminação, que seriam Hamnet, o pai, Anne. Esses símbolos se irradiam na ressurreição do conceito do fantástico com o personagem de Gertrude, ou a Sombra, ou projetada por Horácio, amigo de Hamlet. Ou ainda exteriorizado nesse sujeito

1 Jozef, Bella. Entre la Metafísica y el Tango. Diario La Nación, Buenos Aires, 2000, Suplemento Literario. 
esgotado pelo "fracasso e o furor" privativos da turbulência trágica, levada ao extremo com o príncipe. Lacan o resume poderosamente ao dizer que "a dimensão do fantástico surge quando algo do imaginário do fantasma comunica o que chega normalmente ao nível da mensagem do outro na medida que é o mesmo Eu".2. Então, o Eu do autor fica como espaço de identificações, onde se articularão fenômenos epifânicos, emergindo do desejo inconsciente na poética.

Por outro lado, Hamlet é o paradigma do tratado do mal, do conflito que jaz na alma, que a envolve e a perverte obnubilando a razão. E estas condições serão paradoxalmente a saída de heróis que se liberam de seus tormentos. Mas contrasta com $A$ Tempestade e $O$ Conto do Inverno (1610-11), em que os personagens, ainda que sejam chamados ao horror, se movem em direção ao perdão das ofensas. Além disso, Shakespeare destaca a beleza, a transcendência em um mundo imaginário onde explora os trasfundos como se se tratassem de seu exímio legado do verbo.

Hamlet começa com a morte do pai, instalando-se um clima misterioso invadido por interrogantes, intrigas e efeitos especulares submetidos à função do objeto "a" num jogo de espelhos. A Sombra do pai, no ato I,V, diz: "Eu sou a alma de teu pai, condenada por certo tempo a andar errante de noite e a alimentar o fogo durante o dia, até que estejam extintos e purgados os torpes crimes que na vida cometi. Por não estar-me proibido descobrir os segredos de minha prisão,

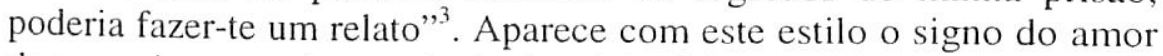
de um pai ameaçador resultado de minha leitura subjetiva que procura desvelar o obscuro de um enigma, similar ao deciframento do sonho. E se faz o dia nesta metáfora paterna, expressão de um saber verdadeiro em meio a um relato tenso em que não se conhecem os subúrbios do crime. Mas advém um tipo de distensão, quando a Sombra confessa a Hamlet: "A serpente que tirou a vida a teu pai hoje cinge sua coroa" ${ }^{\text {, }}$ anunciando-lhe que um veneno foi-lhe vertido no ouvido, com essa característica em Shakespeare de fazer uma confissão sem confissão. "Joga aqui com consonâncias maléficas de

2 Lacan, Jacques. Hamlet, tragédie du désir. Séminaire Inédit. Paris, 1959, p.89.

3 Shakespeare, William. Hamlet. São Paulo, Editora Abril Cultural, Teatro Vivo, 1976, p.50.

4 Ibid 2, p.51. 
um termo que acrescenta o fantástico ao horror de uma situação", E nos brinda com uma parte chave da peça de teatro que a distingue de Édipo, que deseja e mata ele mesmo a seu pai. Ao contrário, Hamlet deseja, mas é outro quem comete o crime. O assassinato significa para o sujeito do inconsciente o gozo compacto de seu desejo parricida",

Por outro lado, William Shakespeare manipula imagens; são imagens duplas que fazem de calambour uma dupla significação, como em The Ghost. Aí adquire uma força encarcerada em significantes de formações do inconsciente que conduzem a significados como os maus sonhos de ambição no ato II, cena 2; e assim surgem brilhos rumo a uma precisão, indo e vindo desde o pitoresco até uma sensualidade inusitada. E, mais tarde, Pascal nos aproxima da idéia de que se fazer de louco seria a política do herói moderno, e nos reúne à loucura fingida de Hamlet para conseguir seu propósito que enlaça a comédia com a tragédia no drama. Shakespeare então salta por cima do sensual, absorvendo-o como na bela cena da pantomima que encerra uma cena/mensagem que revela o crime de Cláudio, mais uma vez mais fracassada, porque Hamlet, o indeciso, não pode matá-lo. Fato a mostrar que, cada vez que deve representar seu ato, Hamlet o representa (mais tarde sumado a esse famoso To be or not to be) sob esse efeito de especulação especularizante sobre o tempo que o encaminha a uma ação impossível. É aquí, diante desse efeito especular de "A", que se percebe também quando o envenenador corteja a Rainha Gertrude, produzindo-se uma metamorfose com a verdade. E se somam constantemente idéias e metáforas que atacam o leitor por todas as partes, exalando a sabedoria mesma do poeta, rompendo a cadência natural da prosa e, por essa via, adquirindo uma linha melódica. Com este Hamlet que se lhe avassalou o corpo do pai de Ofélia, introduz-se um Hamlet preso entre dúvidas nutridas de repúdios sucessivos ao amor, à amizade e à própria honra, e aparece um herói desalentado. Não é por acaso que se erije Hamlet como o protótipo mesmo do homem atormentado, quase incapaz de um gesto que o salvaria da degradação de seu universo, onde ele mesmo se afoga.

E desembocamos em Ofélia. Uma das criações mais sublimes entregues ao romantismo, apanhada também pela loucura como se não

Ibid 2, p.442.

Nasio, Juan David. Les yeux de Laure. Paris: Edition Aubier, 1987, p.102. 
compreendesse o porquê da morte de Polônio e só a percebesse num quadro borrado. Mas seu suicídio ambíguo destaca o dramaturgo em todo seu esplendor. E a tragédia começa. Então, Laertes ruge: "Oh! Que um triplo desastre caia dez vezes triplicado sobre a maldita cabeça daquele cujo iníquo crime te alienou de teu privilegiado entendimento". Ouviu-se: "Aqui está Hamlet, o dinamarquês"”. Momento em que expressa pela primeira vez seu desejo de amor. A verdade inconsciente revelou a intriga; morre Cláudio. Hamlet pede a Horácio que tenha forças para contar esta tragédia, cai, e o poeta the deu um sentido acumulativo ao espanto diante da intolerável visão. E além de injustiças proibidas de fratricídios, adultérios, cobiças, explode o fantástico explorando todo o desconhecido de enunciações reprimidas em uma letra inimitável.

\section{REFERÊNCIAS BIBLIOGRÁFICAS}

JOZEF, Bella. Entre la Metafísica y el Tango. Diario La Nación, Buenos Aires, 2000, Suplemento Literario.

Lacan, Jacques. Hamlet, tragédie du désir. Séminaire Inédit. Paris, 1959.

Nasio, Juan David. Les yeux de Laure. Paris: Edition Aubier, 1987,

Shakespeare, William. Hamlet. São Paulo, Editora Abril Cultural, Teatro Vivo, 1976.

\section{Silvia Beatriz Bolotin}

Montevideo 205

Piso "I" Dpto. "B"

CP: 1019 A.B.E

Buenos Aires

República Argentina

TE. 4832-3296

Fax. 4811-3946

E-mail: sbolotin31@hotmail.com

7. Ibid, 2, p. 212-213. 